\title{
Russia and the Arctic: Environment, Identity and Foreign Policy
}

\author{
Geir Hønneland
}

London \& New York: I.B. Tauris 2016

205 sider. ISBN: 9781784532239

Anmeldt af Jon Rahbek-Clemmensen [ph.d., adjunkt, Institut for Statskundskab, Syddansk Universitet,jrc@sam.sdu.dk]

Ukrainekrisen har selvsagt skabt en grundlæggende bekymring for Ruslands rolle i den europæiske sikkerhedsarkitektur. Hvor Moskva siden Obama-administrationens "genstart« i 2009 har været en forholdsvis konstruktiv samarbejdspartner for Vesten, har tiden siden februar 2014 været præget af spændinger mellem øst og vest, og de senere begivenheder i Syrien har vist at konfliktens ringe berører sikkerhedssituationen udenfor Østeuropa. Analytikere og diplomater med interesse i arktiske forhold har frygtet, at begivenhederne i Kiev, Krim og Donetsk skulle dræbe det velfungerende regionale samarbejde, som Ruslands velvilje har muliggjort i de foregående år. Der har været en stødt stigende interesse $\mathrm{i}$ at forstå Ruslands handlemåde i det høje nord og efterspørgslen efter bøger, artikler og rapporter der tolker Ruslands Arktispolitik har næppe været større.

Et af de bedre værker om dette emne er Geir Hønnelands velskrevne Russia and the Arctic: Environment, Identity and Foreign Policy. Hønneland er en garvet Arktisforsker. Han har beskæftiget sig med emnet siden midt-90'erne - længe før regionen blev »det nye sort« - og hans forskning om samarbejdet i Barentsregionen (BEAR) har fremhævet hvordan det højpolitiske ønske om afspænding efter den kolde krig med nogen succes blev kombineret med samarbejde om lavpraktiske udfordringer, såsom fiskeri-management og grænsestyring. Forholdet mellem høj- og lav-politik har været en rød tråd i store dele af hans forfatterskab og går også igen i Russia and the Arctic.

Bogen har et narrativt og konstruktivistisk udgangspunkt - Hønneland er interesseret i hvordan man taler om Arktis i Rusland, fordi de historier vi fortæller om Arktis afspejler hvordan regionen er en del af vores selvforståelse. Dette narrative fokus er både bogens styrke og dens svaghed. Det adskiller Hønnelands bog fra størstedelen af den eksisterende litteratur om Rusland i Arktis, der typisk tager udgangspunkt i russiske strategier og interesser og forholdet mellem forskellige magtkliker i Kreml. Hønneland breder emnet ud og gennem fire analyser af forskellige emneområder - den igangværende kontinentalsokkelproces, opdelingen af Barentshavet i 2010, administrationen af maritime ressourcer og den regionale 
samarbejde i Barentshavet - åbner han Rusland og særligt de forskellige positioner der udgør den russiske debat om Arktis for læseren. På den måde giver bogen os adgang til oppositionsstemmer som tit bliver glemt $\mathrm{i}$ vestlige beretninger om Rusland.

Et godt eksempel er diskussionen om opdelingen af Barentshavet mellem Norge og Rusland i 2010. Aftalen bliver ofte fremhævet som et godt eksempel på det velfungerende samarbejde i regionen - det arktiske samarbejde må være stærkt, hvis to lande var i stand til at afslutte en fyrre år gammel grænsestrid, der involverede både olie, gas og fiskerirettigheder. Hønneland viser os, at debatten i Rusland ikke var så simpel. Stærke stemmer med kontakter ind i statsadministrationen, såsom Vyacheslav Zilanov, næstformand i det russiske fiskeriagenturs offentlige kammer, kritiserede ikke bare aftalen, men også den daværende præsident Dmitri Medvedev. Hønnelands analyse fremhæver, at Kremls strategiske overvejelser ikke bare afspejler udenrigspolitiske forhold, men at Rusland også har et indenrigspolitisk publikum der skal med på vognen.

Det er enhver anmelders pligt at finde hår $\mathrm{i}$ suppen og denne anmeldelse er ingen undtagelse. Bogens titel fanger ikke dens indhold. Den narrative tilgang giver os et skarpt indblik i debatter der ellers tit er lukket land for de ikke-russisk-kyndige, men, som Hønneland også anerkender, fortæller disse narrativer ikke hele historien om Ruslands tilgang til Arktis. Den brede titel lægger op til et omfattende studie af de mange forskellige dynamikker der driver russisk Arktispolitik, men bogens indhold er langt snævrere: Et studie af russiske narrativer om fire forskellige arktiske emneområder. Hvis man som læser troede at man ville komme til at forstå Russia in the Arctic, vil man blive skuffet.

Desuden kan man undres over hvilke emner Hønneland vælger at dække i sin analyse. Hvor banebrydende (BEAR)-samarbejdet og opdelingen af Barentshavet i 2010 end er, er de vel næppe de vigtigste temaer i russisk Arktispolitik. Nordøstpassagen, regionens betydning for den ubådsbaserede nukleare afskrækkelse og Arktis' potentiale for Ruslands energiindustri er tre betydelige emner der kun får kortvarig opmærksomhed. Her kan man mistænke Hønneland for at være farvet af sin nationalitet. De valgte cases er vigtige i en norsk kontekst og måske er det derfor netop de bliver genstand for hans analyse.

Alt $\mathrm{i}$ alt præsenterer Hønneland en original, vedkommende og særdeles læsværdig analyse af et aspekt af russisk Arktispolitik der ofte glemmes i litteraturen. Den giver et interessant alternativ til mere konventionelle analyser af Rusland i Arktis og kan med fordel ses som et meget relevant supplement til Marlene Laruelles mesterlige Russia's Arctic Strategies and the Future of the Far North. Den vil være vigtig for alle der ønsker at forstå Ruslands komplekse forhold til det høje nord og den udfordring dette medfører for det regionale samarbejde i de kommende år. 